\title{
PENGARUH PEMBERIAN INFORMASI MELALUI BROSUR DAN CERAMAH TERHADAP MINAT DONOR DARAH PEMULA DI SEKOLAH
}

\author{
Yulika Sugesty', Sulastri², Renyep Proborini ${ }^{3}$
}

${ }^{1}$ Fakultas Psikologi Universitas Muhammadiyah Lampung, Bandar Lampung. Email: yulikasugesty53@gmail.com

2Fakultas Psikologi Universitas Muhammadiyah Lampung, Bandar Lampung.

${ }^{3}$ Fakultas Psikologi Universitas Muhammadiyah Lampung, Bandar Lampung.

\section{ABSTRACT: THE EFFECT OF GIVING INFORMATION THROUGH BROCHURE AND LECTURES TO BEGINNER BLOOD DONORS' INTEREST IN SCHOOL.}

Introduction: In order to improve interest in blood donors, one step that can be taken is by giving information and education to change community understanding and behavior about blood donors.

Purpose: This study aims to determine the effect of giving information through brochures and lectures on the interest of beginner blood donors in schools.

Methods: The subjects of this study were 70 students from two classes of $\mathrm{XI}$ in Computer Engineering Network of Natar Budi Karya Vocational School. Interest scale was used as data collection methods and data was analyzed using the Wilcoxon test.

Results: The result obtained shows there is an effect of giving information either through brochures or lectures on the interest of beginner blood donors in schools. There are differences in interest among beginner blood donors between groups given information through brochures and lectures in schools

Conclusion: Brochure found to be more effective than lectures as a media for socialization. It's better for Lampung province UTD PMI officer to give socialization, doing a seminar, and spreading brochure about blood donors in schools so that beginner blood donors interest can be improved

Keywords: brochures, lectures, beginner blood donors

Pendahuluan: Untuk menumbuhkan minat donor darah, salah satu langkah yang dapat diambil adalah pemberian informasi dan edukasi dengan tujuan merubah pemahaman dan perilaku masyarakat terhadap donor darah.

Tujuan: Penelitian ini bertujuan untuk mengetahui pengaruh pemberian informasi melalui brosur dan ceramah tentang minat donor darah pemula di sekolah.

Metode: Subjek penelitian ini adalah 70 siswa dari dua kelas XI di Jaringan Teknik Komputer Sekolah Kejuruan Natar Budi Karya. Metode pengumpulan data menggunakan skala minat dan analisis data menggunakan uji Wilcoxon.

Hasil: Hasil yang didapat menunjukkan adanya pengaruh pemberian informasi baik melalui brosur maupun melalui ceramah terhadap minat donor darah pemula di sekolah. Lebih lanjut, juga ditemukan adanya perbedaan minat donor darah pemula antara kelompok yang diberi informasi melalui brosur dan ceramah di sekolah.

Simpulan: Brosur ditemukan lebih efektif daripada metode ceramah sebagai media sosialisasi. Kepada petugas UTD PMI Provinsi Lampung sebaiknya lebih banyak memberikan sosialisasi, mengadakan seminar dan penyebaran brosur di sekolah-sekolah yang bertujuan meningkatkan minat donor darah pemula di sekolah.

Kata Kunci: brosur, ceramah, minat donor darah pemula

\section{PENDAHULUAN}

Pelayanan transfusi darah sebagai salah satu upaya kesehatan dalam rangka penyembuhan penyakit dan pemulihan kesehatan yang sangat membutuhkan kesediaan darah atau komponen darah yang cukup, aman, berkualitas, mudah diakses dan terjangkau oleh masyarakat.Kesediaan darah tergantung kepada minat masyarakat untuk mendonorkan darah secara sukarela dan teratur.Berdasarkan dokumen data pada tahun 2016, Unit Transfusi Darah Provinsi Lampung memiliki pendonor sukarela sebanyak 30.847 orang dan 10.007 orang pendonor pengganti.Dari data tersebut 


\section{PENGARUH PEMBERIAN INFORMASI MELALUI BROSUR DAN CERAMAH TERHADAP MINAT DONOR DARAH} PEMULA DI SEKOLAH

masih ada kekurangan untuk memenuhi target 100 persen pendonor sukarela.

Untuk menumbuhkan minat untuk mendonor darah, salah satu langkah yang dapat diambil adalah pemberian informasi dan edukasi dengan tujuan merubah pemahaman dan perilaku masyarakat terhadap donor darah(Kemenkes, 2015)..Beberapa upaya pemberian informasi dan edukasi yang sudah dilakukan adalah pemberian brosur dan ceramah kepada calon pendonor pemula.Target dari Palang Merah Indonesia adalah, anggota masyarakat yang awalnya terpaksa mendonorkan darah menjadi pendonor rutin.

Minat menurut Hurlock (2001), merupakan sumber motivasi yang mengarahkan seseorang pada apa yang akan mereka lakukan bila diberi kebebasan untuk memilih. Menurut Hurlock aspek minat terbagi menjadi 2 yaitu : (1) Aspek kognitif yang ditandai dengan adanya kebutuhan akan informasi dan adanya rasa ingin tahu, (2) Aspek afektif yang mengiringi sikap terhadap kegiatan atau objek yang menimbulkan minat. Aspek ini mempunyai peranan yang besar dalam memotivasi tindakan seseorang. Menurut Dahar (2007), aspek afektif mencakup watak dari perilaku seseorang seperti perasaan, minat, sikap, emosi, dan nilai. Pengertian yang sama menurut Tohirin (2007), perilaku afektif adalah perilaku yang menyangkut keanekaragaman perasaan, seperti suka, takut, marah, sedih, gembira, kecewa, senang, benci, was-was dan sebagainya.

Menurut KKBI, Donor adalah penderma; pemberi sumbangan; penderma darah (yang menyumbangkan darahnya untuk menolong orang lain yang memerlukan). Donor darah adalah proses pengambilan darah dari seseorang secara sukarela untuk disimpan di Bank Darah untuk dipakai pada keperluan transfusi darah (Darajatun, 2008). Pemula menurut Kamus Besar Bahasa Indonesia (2015), orang yang mulai atau mula-mula melakukan sesuatu.Dari uraian tersebut dapat disimpulkan bahwa minat donor darah pemula adalah motivasi orang untuk mulai mendermakan darahnya.

Semakin pentingnya donor darah dari semua lini, khususnya pendonor pemula yang menguasai sebagai besar rentang usia produktif, maka penelitian ini bertujuan untuk melihat pengaruh pemberian informasi melalui brosur dan ceramah tentang minat donor darah pemula di sekolah.

\section{METODE}

Penelitian ini adalah Quasi eksperiment (eksperimen semu) dengan rancangan non equivalen pretest-posttest design., biasanya dipakai pada eksperiment dengan memilih kelas-kelas yang diperkirakan tidak sama keadaan/kondisinya. Dua kelas ini diberi pretest, kemudian diberikan perlakuan, dan terakhir diberikan posttest. Tidak terdapat kelompok kontrol, karena kedua kelas ini sama-sama belum pernah mendonorkan darah. Adapun populasi dalam penelitian ini adalah siswa kelas XI TKJ SMK Budi Karya Natar. Sekolah ini dipilih peneliti dikarenakan belum pernah melakukan donor darah dan lokasi yang cukup jauh dari UTD PMI. Perlakuan yang diberikan dalam penelitian ini ada dua yaitu pemberian informasi melalui ceramah dan pemberian informasi melalui bosur. Informasi yang dimaksudkan adalah informasi seputar donor darah. Pengukuran minat donor darah dilakukan dengan menggunakan skala likert yang sudah valid dan reliabel.

Pada penelitian ini analisis data menggunakan Paired T-Test yaitu uji komparatif atau uji beda untuk mengetahui adakah perbedaan mean atau rerata yang bermakna antara 2 kelompok bebas yang berskala data interval / rasio. Uji Paired T-Test atau Wilxocon jika dua data yang dibandingkan terdistribusi normal maka dilakukan uji Paired T- Test, tetapi apabila salah satu dari data yang dibandingkan tidak terdistribusi normal dilakukan uji Wilcoxon. Dua kelompok bebas yang dimaksud adalah dua kelompok yang tidak berpasangan artinya sumber data dari subjek yang berbeda dan menggunakan dengan sistem komputerisasi melalui program SPSS 16.0 for windows.

Berikut adalah desain eksperimennya

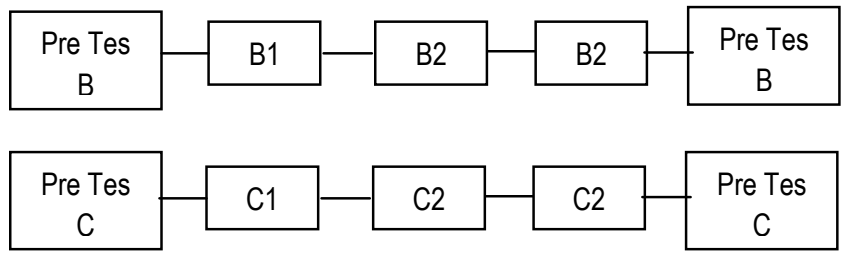

Yulika Sugesty, Fakultas Psikologi Universitas Muhammadiyah Lampung, Bandar Lampung. Email: yulikasugesty53@gmail.com

Sulastri, Fakultas Psikologi Universitas Muhammadiyah Lampung, Bandar Lampung.

Renyep Proborini, Fakultas Psikologi Universitas Muhammadiyah Lampung, Bandar Lampung. 


\section{PENGARUH PEMBERIAN INFORMASI MELALUI BROSUR DAN CERAMAH TERHADAP MINAT DONOR DARAH} PEMULA DI SEKOLAH

Keterangan:

Pretes B : Pretes minat donor darah kelas XI F sebelum diberi brosur

B1, B2, B3 : Pemberian brosur sebanyak 3 kali pertemuan dalam selang waktu 4 hari dari setiap pemberian

Postes B : Postes minat donor darah setelah diberikan brosur
Pretes C : Pretes minat donor darah kelas XI G sebelum diberi ceramah

C1,C2,C3 : Pemberian ceramah sebanyak 3 kali pertemuan dalam selang waktu 4 hari dari setiap pemberian.

Postes C : Postes minat donor darah setelah diberikan ceramah pada Kelas XI G

HASIL

Tabel 1.

Descriptive Statistics

\begin{tabular}{lccccc}
\hline & N & Min. & Max. & Mean & SD \\
\hline Minat (Sebelum Pemberian Brosur) & 28 & 63 & 96 & 83.61 & 7.809 \\
Minat (Sesudah Pemberian Brosur) & 28 & 83 & 117 & 94.75 & 7.245 \\
Minat ( Sebelum Pemberian Ceramah) & 28 & 67 & 96 & 83.68 & 7.429 \\
Minat ( Sesudah Pemberian Ceramah) & 28 & 87 & 112 & 92.18 & 8.060 \\
$\quad$ Valid N (listwise) & $\mathbf{2 8}$ & & & & \\
\hline
\end{tabular}

Dari tabel di atas untuk masing-masing variabel yaitu: untuk variabel minat sebelum pemberian brosur diketahui nilai rata-rata adalah 83,61 , untuk variabel minat sesudah pemberian brosur diketahui nilai rata-rata adalah 94,75 . Selanjutnya untuk variabel minat sebelum pemberian ceramah diketahui nilai rata-rata adalah 83,68 untuk variabel minat sesudah pemberian ceramah nilai rata-rata adalah 92,18 . Terjadi juga peningkatan pada nilai rata-rata setelah dilakukan post test.

Setelah uji normalitas dilakukan, salah satu dari data sesudah ceramah yang dibandingkan tidak terdistribusi normal, maka dilakukan uji Wilcoxon yang dilihat dari pretest-posttest dua minggu untuk kedua variabel yang diteliti.Uji ini untuk mengetahui apakah ada pengaruh minat donor darah pemula di sekolah.

Tabel 8.

Rank Pemberian Infomasi Brosur

\begin{tabular}{llccc}
\hline & N & Mean Rank & Sum of Ranks \\
\hline $\begin{array}{l}\text { Minat (Sesudah Brosur)- } \\
\text { (Sebelumat Brosur) }\end{array}$ & Negative Ranks & $5^{\mathrm{a}}$ & 6.80 & 34.00 \\
& Positive Ranks & $20^{\mathrm{b}}$ & 14.55 & 291.00 \\
& Ties & $3^{\mathrm{c}}$ & & \\
& Total & $\mathbf{2 8}$ & & \\
\hline
\end{tabular}

a. Minat (Sesudah Brosur) $<$ Minat (Sebelum Brosur)

b. Minat (Sesudah Brosur) $>$ Minat ( Sebelum Brosur)

c. Minat (Sesudah Brosur) $=$ Minat ( Sebelum Brosur)

Dari tabel di atas diketahui dari 28 data mempunyai data negatif 4 data, dan 21 data bernilai positif.Dari hasil uji statistik diatas ditemukan $\mathrm{p}=.000(\mathrm{p}<.05)$ maka HO ditolak sehingga dapat disimpulkan terdapat pengaruh pemberian informasi melalui brosur terhadap minat donor darah pemula di SMK Budi Karya Natar.

Yulika Sugesty, Fakultas Psikologi Universitas Muhammadiyah Lampung, Bandar Lampung. Email: yulikasugesty53@gmail.com

Sulastri, Fakultas Psikologi Universitas Muhammadiyah Lampung, Bandar Lampung.

Renyep Proborini, Fakultas Psikologi Universitas Muhammadiyah Lampung, Bandar Lampung. 


\section{PENGARUH PEMBERIAN INFORMASI MELALUI BROSUR DAN CERAMAH TERHADAP MINAT DONOR DARAH} PEMULA DI SEKOLAH

Tabel 9.

Rank Pemberian Infomasi Ceramah

\begin{tabular}{llccc}
\hline & & N & Mean Rank & Sum of Ranks \\
\hline $\begin{array}{l}\text { Minat (Sesudah Ceramah) } \\
\text { Minat (Sebelum Ceraman) }\end{array}$ & Negative Ranks & $1^{\text {a }}$ & 4.75 & 9.50 \\
& Positive Ranks & $26^{b}$ & 15.76 & 396.50 \\
& Ties & $0^{c}$ & & \\
& Total & $\mathbf{2 8}$ & & \\
\hline
\end{tabular}

a) Minat (Sesudah Ceramah) < Minat (Sebelum Ceramah)

b) Minat (Sesudah Ceramah) $>$ Minat (Sebelum Ceramah)

c) $\quad$ Minat (Sesudah Ceramah) $=$ Minat (Sebelum Ceramah)

Dari tabel diatas diketahui dari 28 data mempunyai data negatif 1 data, dan 27 data bernilai positif. Dari hasil uji statistik diatas ditemukan $\mathrm{p}=.000(\mathrm{p}<.05)$ maka $\mathrm{HO}$ ditolak sehingga dapat disimpulkan terdapat pengaruh pemberian informasi melalui ceramah terhadap minat donor darah pemula di SMK Budi Karya Natar.

Hipotesis ke tiga adalah terdapat perbedaan minat donor darah pemula antara kelompok yang diberi informasi melalui brosur dan ceramah di SMK Budi Karya Natar dilakukan dengan uji wilxocon.Dari hasil uji statistik ditemukan nilai $p=.02(p<.05)$, maka HO ditolak, berarti antara sesudah pemberian informasi melalui brosur dan sesudah pemberian informasi melalui ceramah terbukti terdapat perbedaan sehingga ketiga diterima, yaitu terdapat perbedaan minat donor darah pemula antara kelompok yang diberi informasi melalui brosur dan ceramah di SMK Budi Karya Natar.

\section{DISKUSI}

Berdasarkan uji hipotesis 1 disimpulkan bahwa terdapat pengaruh pemberian informasi melalui brosur terhadap minat donor pemula di SMK Budi Karya Natar. Hal ini didukung oleh data deskriptif bahwa rata-rata sebelum pemberian brosur $=83,61$ dan sesudah pemberian brosur $=94,75$, sehingga terdapat lonjakan minat untuk donor pemula yang signifikan. Peningkatan minat responden mencerminkan peningkatan minat dipengaruhi adanya bantuan media yang lebih memudahkan responden dalam mengingat materi yang diberikan, dan dalam penelitian ini media yang digunakan brosur. Sejalan dengan faktor yang mempengaruhi minat menurut Sukmadinata (2010) diantaranya: pengetahuan, pengalaman dan informasi. Dengan adanya penambahan pengetahuan, proses dari tidak tahu menjadi tahu, pada awalnya donor darah pemula tidak mengetahui informasi tentang donor darah menjadi lebih tahu.Pengalaman yang merupakan pengulangan yang didapatkan setelah pemberian brosur.

Hasil uji hipotesis ke 2 dapat disimpulkan bahwa terdapat pengaruh pemberian informasi melalui ceramah terhadap minat donor darah pemula di SMK Budi Karya Natar.Nilai rata-rata minat sebelum pemberian ceramah 83,68 dan minat sesudah pemberian brosur terjadi peningkatan yaitu 92,18 . Dapat disimpulkan bahwa ada pengaruh pemberian informasi melalui ceramah terhadap minat pendonor pemula.Peningkatan minat yang terjadi sesudah pemberian informasi ceramah dapat disebabkan oleh ceramah yang diberikan. Dengan dilakukan ceramah, akan meningkatkan minat responden sehingga akan berpengaruh terhadap minat yang diambil. Pada penelitian ini didapatkan peningkatan minat responden setelah dilakukan pemberian informasi melalui ceramah. Menurut Notoatmodjo (2013), metode ceramah merupakan suatu cara dalam menerangkan dan menjelaskan suatu ide, pengertian atau pesan secara lisan kepada kelompok sasaran sehingga memperoleh informasi. Dengan metode ceramah ini pendonor pemula mendapatkan informasi dengan pesan yang tersampaikan secara lisan sehingga mudah ditangkap oleh pendonor pemula.

Hasil uji hipotesis ke 3 dapat disimpullkan bahwa terdapat perbedaan minat donor darah pemula antara kelompok yang sesudah diberikan informasi melalui brosur dan ceramah di SMK Budi Karya Natar. Terjadi

Yulika Sugesty, Fakultas Psikologi Universitas Muhammadiyah Lampung, Bandar Lampung. Email:

yulikasugesty53@gmail.com

Sulastri, Fakultas Psikologi Universitas Muhammadiyah Lampung, Bandar Lampung.

Renyep Proborini, Fakultas Psikologi Universitas Muhammadiyah Lampung, Bandar Lampung. 


\section{PENGARUH PEMBERIAN INFORMASI MELALUI BROSUR DAN CERAMAH TERHADAP MINAT DONOR DARAH} PEMULA DI SEKOLAH

peningkatan diantara sebelum dan sesudah pemberian informasi melalui brosur mengalami peningkatan sebanyak 11,14. Dan juga terjadi peningkatan minat diantara sebelum dan sesudah pemberian informasi melalui ceramah mengalami peningkatan 8,5. Minat adalah suatu rasa lebih suka dan rasa keterikatan pada suatu hal atau aktivitas tanpa ada yang menyuruh.

Dalam Notoadmodjo (2010), pemberian informasi secara formal maupun non formal dapat meningkatkan pengetahuan. Pemberian media brosur merupakan salah satu pemberian informasi secara non informal yang sering digunakan di dunia kesehatan.Peningkatan sesudah pemberian brosur lebih tinggi dibanding sesudah pemberian ceramah.Stimulus (rangsangan) yang diberikan diterima oleh siswa, dengan adanya brosur yang dibagikan dapat dibaca berulang-ulang, sedangkan ceramah hanya diterima di kelas.Media brosur dapat diperoleh dengan mudah serta efektif digunakan sebagai media informasi.Sebagai media informasi, gambar atau foto dipillih atau digunakan sesuai dengan tujuan yang telah ditetapkan.Dengan adanya gambar atau foto dapat membangkitkan minat untuk menafsirkan serta mengingat pesan yang berkenaan dengan gambar atau foto tersebut.Brosur lebih efektif dibagikan di sekolah karena brosur adalah media yang dapat dibaca berulang kali, mudah dibawa, dan ekonomis. Asumsi akan adanya pengulangan dalam membaca brosur dapat lebih meningkatkan intensitas pemberian informasi mengenai donor darah. Hal ini akan meningkatkan pengetahuan yang lebih besar dibandingkan dengan pemberian ceramah. Sehingga minat untuk menjadi donor pemula lebih tinggi pada kelompok siswa yang diberikan brosur.

\section{SIMPULAN \& SARAN}

Berdasarkan hasil analisis data dan pembahasan yang telah diuraikan sebelumnya maka dapat ditarik kesimpulan bahwa terdapat pengaruh pemberian informasi melalui brosur terhadap minat donor darah pemula di SMK Budi Karya Natar. Selain itu juga terdapat pengaruh pemberian informasi melalui ceramah terhadap minat donor darah pemula di SMK Budi Karya Natar.Pengaruh pemberian informasi melalui brosur dan ceramah terhadap minat donor darah pemula di SMK Budi Karya Natar juga terbukti.

Berdasarkan hasil penelitian dan kesimpulan yang diperoleh, maka peneliti memberikan saran sebagai berikut:

1. Kepada petugas UTD PMI Provinsi Lampung agar memberikan sosialisasi, mengadakan seminar dan penyebaran brosur di sekolah-sekolah yang bertujuan meningkatkan minat donor darah pemula di sekolah.

2. Untuk peneliti selanjutnya bahwa kelemahan dari penelitian ini adalah hanya diberikan waktu singkat oleh pihak sekolah, dan tidak adanya kontrol terhadap pengetahuan tentang donor darah, sehingga hal tersebut akan mempengaruhi hasil penelitian.

3. Saran aplikasi bahwa ternyata lebih efektif penggunaan brosur dibandingkan ceramah untuk menarik minat pendonor pemula.

\section{DAFTAR PUSTAKA}

Dahar, R. W. (2011). Teori-teori belajar dan pembelajaran. Jakarta: Erlangga, 136, 141.

Daradjatun.(2008). Pedoman Pelayanan Tranfusi Darah. Jakarta: UTD.PMI Pusat

Dewi, R. R. K., Kartasurya, M. I., \& Mawarni, A. (2017). Analisis Kebijakan Donor Darah Dan Implementasi Program Rekrutmen Donor Di Unit Donor Darah (UDD PMI) Kota Pontianak. Jurnal Manajemen Kesehatan Indonesia, 4(2), 109-117.

Yulika Sugesty, Fakultas Psikologi Universitas Muhammadiyah Lampung, Bandar Lampung. Email: yulikasugesty53@gmail.com

Sulastri, Fakultas Psikologi Universitas Muhammadiyah Lampung, Bandar Lampung.

Renyep Proborini, Fakultas Psikologi Universitas Muhammadiyah Lampung, Bandar Lampung. 
PENGARUH PEMBERIAN INFORMASI MELALUI BROSUR DAN CERAMAH TERHADAP MINAT DONOR DARAH PEMULA DI SEKOLAH

Hurlock, E.B. (2001). Psikologi Perkembangan: Suatu pendekatan sepanjang rentang kehidupan (Edisi 5). Jakarta: Erlangga.

dari https://www.persi.or.id/images/regulasi/permen kes/pmk912015.pdf

Notoatmodjo, S. (2010). Metodologi penelitian kesehatan.

Nasional, D. P. (2014). Kamus Besar Bahasa Indonesia Pusat Bahasa Edisi Ketujuh. Jakarta: PT Gramedia Pustaka Utama.

Peraturan Menteri Kesehatan. (2004). Nomor 83 Unit Transfusi Darah, Bank Darah Rumah Sakit, dan Jejaring Pelayanan Transfusi Darah. Jakarta: Departemen Kesehatan RI

Sukmadinata, Nana Syaodih. (2010). Pengaruh Minat Belajar dan Lingkungan Sekolah. Jakarta: Bumi Aksara

Tohirin. (2007). Bimbingan dan Konseling disekolah dan Madrasah. Jakarta: Raja Grafindo Persada

Who.(1994). Pedoman Pelayanan Transfusi Darah. Jakarta: Depkes RI

Peraturan Menteri Kesehatan. (2015). Nomor 91 Tentang Standar Pelayanan Transfusi Darah. Jakarta: Departemen Kesehatan Rl. Diunduh

Yulika Sugesty, Fakultas Psikologi Universitas Muhammadiyah Lampung, Bandar Lampung. Email: yulikasugesty53@gmail.com

Sulastri, Fakultas Psikologi Universitas Muhammadiyah Lampung, Bandar Lampung.

Renyep Proborini, Fakultas Psikologi Universitas Muhammadiyah Lampung, Bandar Lampung. 